\title{
EVALUATION OF TRENDS IN FOREIGN TRADE DEVELOPMENT IN THE POST-COMMUNIST COUNTRIES OF EUROPE IN THE YEARS 2000-2012 FOLLOWING THEIR ACCESSION TO THE EU
}

\author{
Ewa Cieślik ${ }^{1}$, Jadwiga BiegańsKa ${ }^{2}$, Stefania Środa-Murawska ${ }^{2}$ \\ ${ }^{1}$ Faculty of International Business and Economics, University of Economics and Business, Poznań, Poland \\ ${ }^{2}$ Department of Urban Studies and Regional Development, Nicolaus Copernicus University in Torun, Poland
}

Manuscript received: April 4, 2016

Revised version: September 21, 2016

CieŚlik E., Biegańska J., ŚRoda-Murawska S., 2016. Evaluation of trends in foreign trade development in the post-communist countries of Europe in the years 2000-2012 following their accession to the EU. Quaestiones Geographicae 35(4), Bogucki Wydawnictwo Naukowe, Poznań, pp. 35-48, 7 tables, 6 figs.

AвSTRACT: This paper seeks to analyse directions in foreign trade in the post-communist countries of Europe over the years 2000-2012 in the context of changes observed in other EU states. It was assumed that changes in the directions of foreign trade in post-communist states would be similar to those noted in Western Europe. On the basis of data derived from the OECD, EUROSTAT and OECD-WTO we show that the trading rules used by the old EU-15 adopted by those countries have brought them measurable benefits. As a result, the post-communist economies have become similar to those of the EU-15. Considering the structure of their trade and links with the EU-15, it is apparent that they have become the main trading and investment partners for the European Union. Hence, their integration with the EU structures made their development faster, but also made them more sensitive to industrial and demand shocks coming from the eurozone. It is predicted that the present model is not going to change, especially in the context of the participation in production networks.

KEY WORDS: Central and Eastern Europe, EU, foreign trade, post-communist countries, intra-regional trade, trade links

Corresponding author: Jadwiga Biegańska, Department of Urban Studies and Regional Development, Nicolaus Copernicus University, Lwowska 1,87-100 Toruń, Poland; e-mail: jadwigab@umk.pl

\section{Introduction}

With the collapse of the USSR, its satellite countries had to make concrete improvements in all aspects of economic life. Because, theoretically, all those countries were at a stage where a profound systemic transformation was inevitable (there were many signs of their substantial underdevelopment relative to developed countries), opportunities for cooperation and integration were many ${ }^{1}$. The factors that were to become particularly important as drivers of their integration process and socio-economic

\footnotetext{
1 In practice, integration processes had different intensities. In addition to the countries showing different interest in cooperation, other major obstacles included different levels of their development, shortages of capital, unavailability of modern technologies, similarities between economic structures, and, quite frequently, national resentment, and limited trust in the partner (Świerkocki 2004).
} 
development included the growing openness of their economies and their ability to use the chances of globalisation ${ }^{2}$. Integration processes were also stimulated by the redefinition of the exchange rate determination systems and the relaxation of rules governing financial sectors (Tymoczko 2013).

The formation of the CEFTA ${ }^{3}$ (Central European Free Trade Area) and BFTA (Baltic Free Trade Area) associating Lithuania, Latvia and Estonia were milestones that contributed to the strengthening of trade links among the post-communist countries. The main goal of both organisations was to make their members ready for integration with the European Union, to gradually liberate foreign trade from the old constraints and, ultimately, to create free-trade areas (Dangerfield 1995). As well as being an important stepping stone towards those countries' entry into the EU structures, the organisations also had a major effect on the shape of trade in the CEE region, effectively weakening the influence of the European Community perceived as a centre determining the structure and rules of trade in the region (De Benedictis et al. 2005) ${ }^{4}$.

The provisions of the CEFTA agreement had a greater scope than other free-trade agreements of this kind (Sołtysińska, Czubik 1997). The CEFTA was largely modelled after the association agreements negotiated with the European Community, but contained also a number of clauses (an agricultural clause, an anti-dumping clause, a state-aid clause, etc.) aimed to protect the fledgling markets of its member states and establish the rules of origin. The primary goal of the CEFTA was to:

- boost trade and thereby to take economic relations to a higher level;

- base trade on fair competition rules; and

However, the literature on this subject is not clear on how exactly economic openness (trade and capital flows) contribute to the development of a country (Cieślik 2012).

3 The three founding countries were Poland, Hungary and Czechoslovakia. After a time, they were joined by Slovenia, Romania, Bulgaria, Croatia, Macedonia. Albania, Bosnia and Herzegovina, Moldavia, Montenegro, and Serbia.

4 It is worth noting that later on 10 states of South-Eastern Europe formed CEFTA-2006 (Kersan-Škabić 2009).
- remove foreign trade constraints to enable sustainable development and expansion of world trade (Molendowski 2012).

The BFTA agreement was basically designed along the same lines. Its main goals were to liberalise trade and foster sustainable development of economic relations among its members, to enable fair competition, and to improve cooperation in economic areas not covered by the agreement, such as capital flows (Molendowski 2009). Unlike the CEFTA, the BFTA did not provide the admission of new members. Its scope included a range of politically sensitive cooperation issues, such as fishery and agriculture (World Bank 2010).

The EU countries were initially pessimistic about whether the CEFTA and BFTA members would be able to cooperate and cope with the complex structure of the EU. The latter, in turn, were concerned that they would increase their exposure to shocks coming from the EU once they have become members (Baldwin 1995). This situation made the CEFTA and BFTA pursue two goals at the same time. First, they became a testing ground for their members' ability to cooperate at many economic levels, particularly in the sphere of trade. Secondly, by strengthening trade links among its members they wanted to make their signatories less dependent on the EU markets. The CEFTA and BFTA can be perceived as an attempt at replacing the hub-and-spoke model of trade with the EU by giving stronger support to trade within the groups at the cost of trade with the EU member states (Baldwin 1994).

The CEFTA and BFTA countries were relatively successful in achieving the first of the goals. By extending their influence and admitting new members (CEFTA), in the 1990s the organisations were the most important forces accelerating the liberalisation of trade flows in CEE. As far as the second goal is concerned, the organisations were less effective. Decreasing the dependence on EU markets by increasing the volume of trade inside the organisations proved difficult to achieve, not only because those markets welcomed CEE exports, but also because the EU countries supplied many goods that post-communist countries did not produce. Despite the CEFTA and BFTA efforts to restrict the growth of the dependence on the EU by stimulating internal flows of goods and services, the process was inevitable. The statistics of the International Monetary Fund show that 
in 1993 the CEFTA and BFTA sold, respectively, $56 \%$ and $50 \%$ of their exports on the EU markets. In 2001, the rates already amounted to $68 \%$ and 55\% (IMF 2014). Although the CEFTA and BFTA failed to attain most of their strategic goals, they were frequently given as an example of integration for countries in South-Eastern Europe to follow (Adam et al. 2003).

In the pre-accession period, the goals pursued by the post-communist countries and the EU were somewhat asymmetric. While the EU states wanted to lift trade barriers as soon as possible, particularly those constraining trade in products in which the candidate countries had a comparative advantage, the latter preferred to delay the full liberalisation of trade flows to a later date.

The turning point in the trade policy of the European post-communist countries was their entry into the European Union ${ }^{5}$. As full partners in the Single European Market, they had to basically redefine the rules governing their foreign trade and to adopt all laws and instruments of the EU's trade policy towards third countries (Kawecka-Wyrzykowska 2009, Cieślik 2012, Cieślik et al. 2016). The adoption of the EU legislation on the free movement of goods amounted to the abolishment of customs duties and similar charges, the revocation of quotas and anti-dumping laws, as well as the removal of all physical, technical and fiscal barriers that had been used to control cross-border traffic. In trade with nonEU countries, the new (post-communist) member states had to abide by the rules of the common trade policy. Their previous autonomy in developing and regulating trade relations with other countries was now replaced by their formal subordination to EU legislation. All measures used to protect national markets had to be harmonised with those in force in the EU, and all powers their governments could exercise to control the above areas were handed over to EU institutions. All those changes did not improve the access of the new member states to markets in non-EU countries. In some cases (e.g. trade with the USA and Canada) the conditions on which they traded with them even worsened (Synowiec 2004, Molendowski 2012).

\footnotetext{
Poland, the Czech Republic, Slovakia, Slovenia, Hungary and the BFTA countries became EU members on 1 May 2004, and Bulgaria and Romania on 1 January 2007.
}

This paper seeks to analyse directions of foreign trade in the post-communist countries of Europe over the years 2000-2012 in the context of changes observed in other EU states. We believe that this period shows changes in foreign trade of post-communist countries before and after their EU accession. We assumed that changes in the directions of foreign trade in the post-communist states would be similar to those noted in Western Europe. Against the background of the following features describing the development of the economies of the former communist states:

- the openness of the post-communist countries to the world,

- the contribution of the post-communist countries to global exports and imports of commodities and services, and

- the current account balance as a share of the GDP,

we analyse indicators which enable an analysis of changes in the directions of the development of foreign trade (export and import concentration indices; changes in the commodity structure of exports; and indicators of revealed comparative advantage $\left(R C A_{j}\right)$ ). The source data were derived from databases kept by international organisations, mainly the OECD, EUROSTAT and OECD-WTO.

\section{Foreign trade changes in the post- communist countries of Europe: general statistics}

After 2000, foreign trade volumes in post-communist countries expanded at a fast rate, considerably exceeding the EU average. From 2000 to 2012 the growth rates of exports and imports kept rising, respectively, by almost $16 \%$ and $13.7 \%$ a year. However, the beginning of the global economic crisis rapidly and severely reduced foreign trade volumes in those countries ${ }^{6}$, the most affected being Lithuania ${ }^{7}$. In 2008, a slow recovery

6 In the analysed countries, the growth rate of exports decreased from $18 \%$ in Romania to even 30\% in Lithuania. The volumes of imports decreased even more, particularly in Lithuania $(-41 \%)$. The smallest decrease was noted in Slovakia (-24.7\%) (Eurostat 2014).

7 The main reason why Lithuanian exports collapsed was the rapidly falling oil prices that were high before the crisis. 


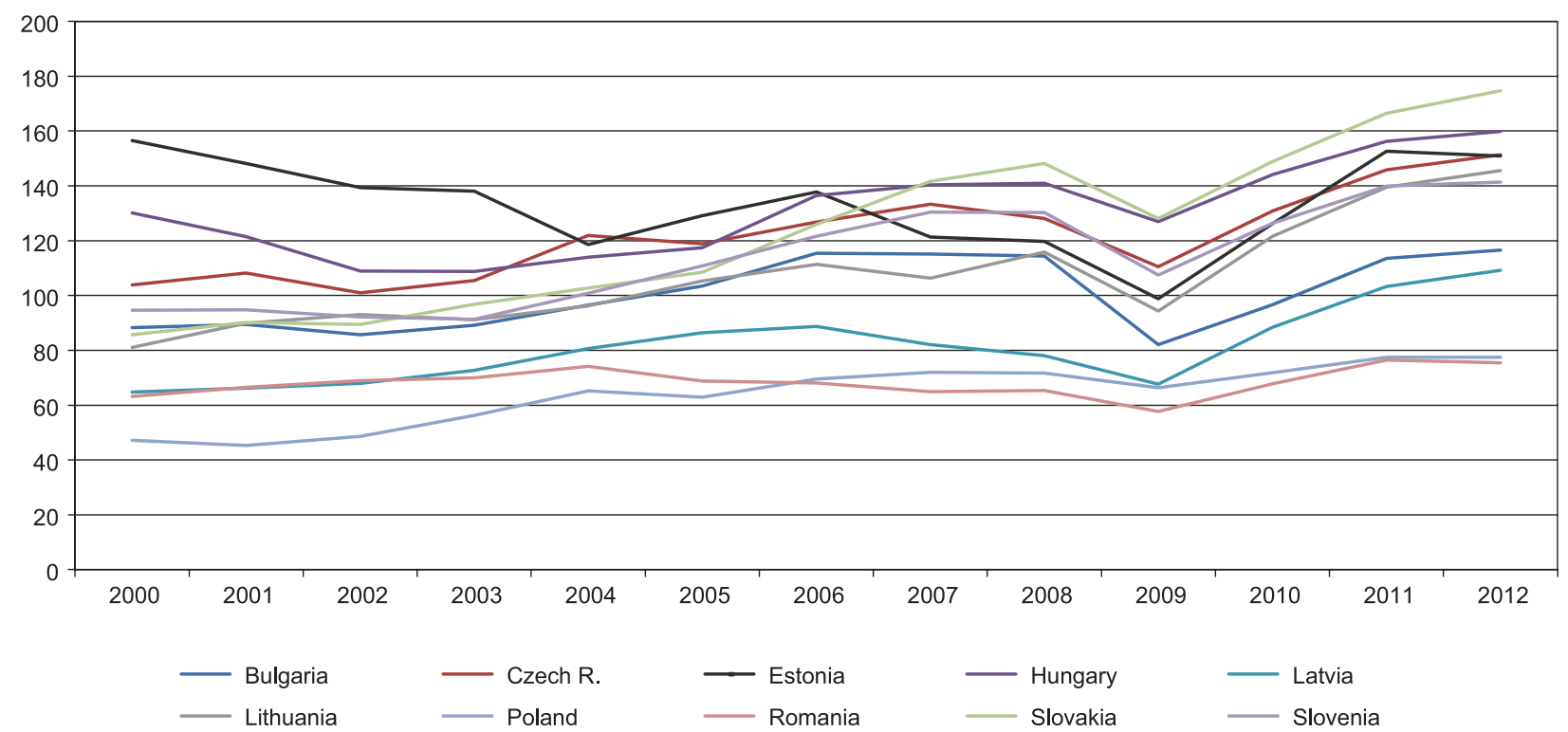

Fig 1. The openness of post-communist countries to the world, the years 2000-2012.

Source: calculated by the authors on the basis of the World Integrated Trade Solution data, the World Bank.

began, but trade volumes did not return to the pre-crisis levels until 2011.

A more detailed analysis of the growth rates of exports and imports recorded in the post-communist countries shows that their values were the highest in the first years following their entry into the EU structures. Then they increased their trade with the EU-15 and non-EU countries, as well as with other countries in the CEE region. The highest rates of growth were recorded for trade in goods and services among the new member states (OECD 2014).
The post-communist economies are characterised by greater openness of foreign trade, defined as the ratio between the trade value and the GDP, than the world average. The ratios were particularly high in Slovakia (175\%) and Hungary (160\%). The 2012 value of $77 \%$ ranked Poland among the last countries in the classification (Fig. 1).

Despite the high rates of openness to the world of the new member states, their share in the global trade volume is small compared with such leaders as the USA, China, or Germany. The share kept expanding until the year when the global crisis occurred. In the next years, their

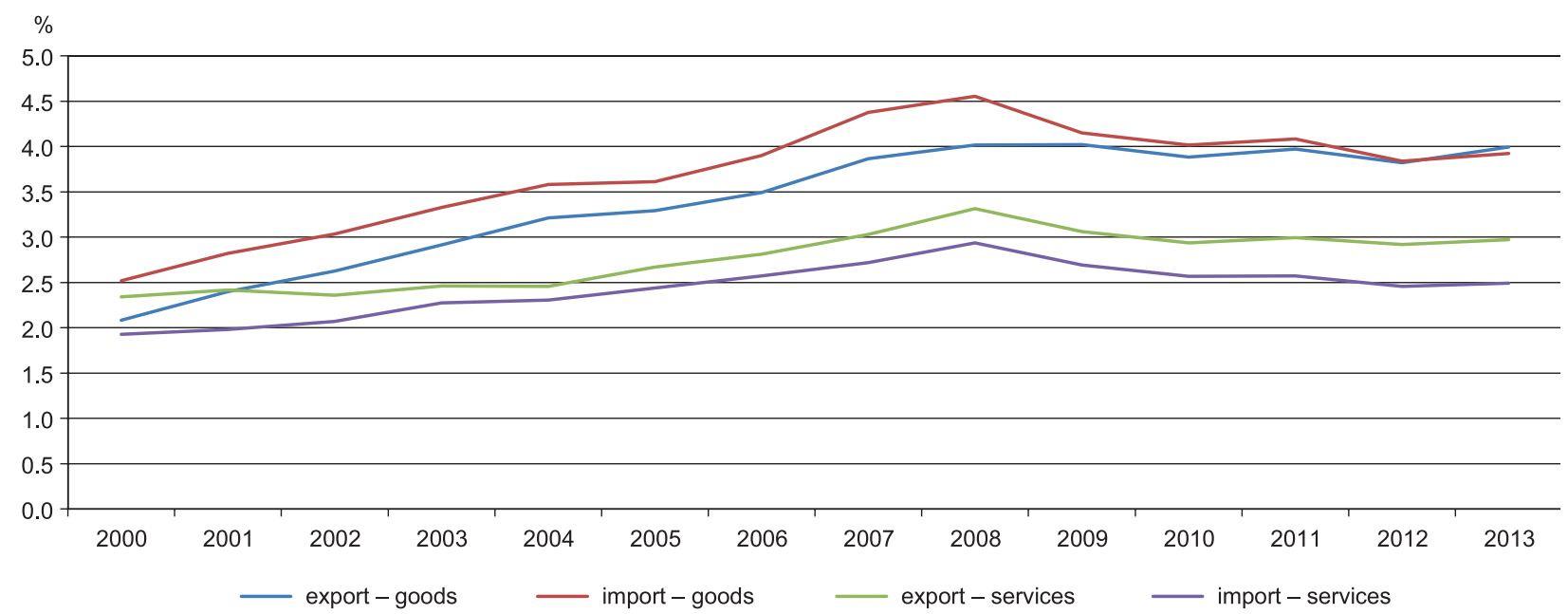

Fig. 2. The contribution of post-communist countries to global exports and imports of commodities and services, the years 2000-2012.

Source: developed by the authors on the basis of the OECD-WTO data. 


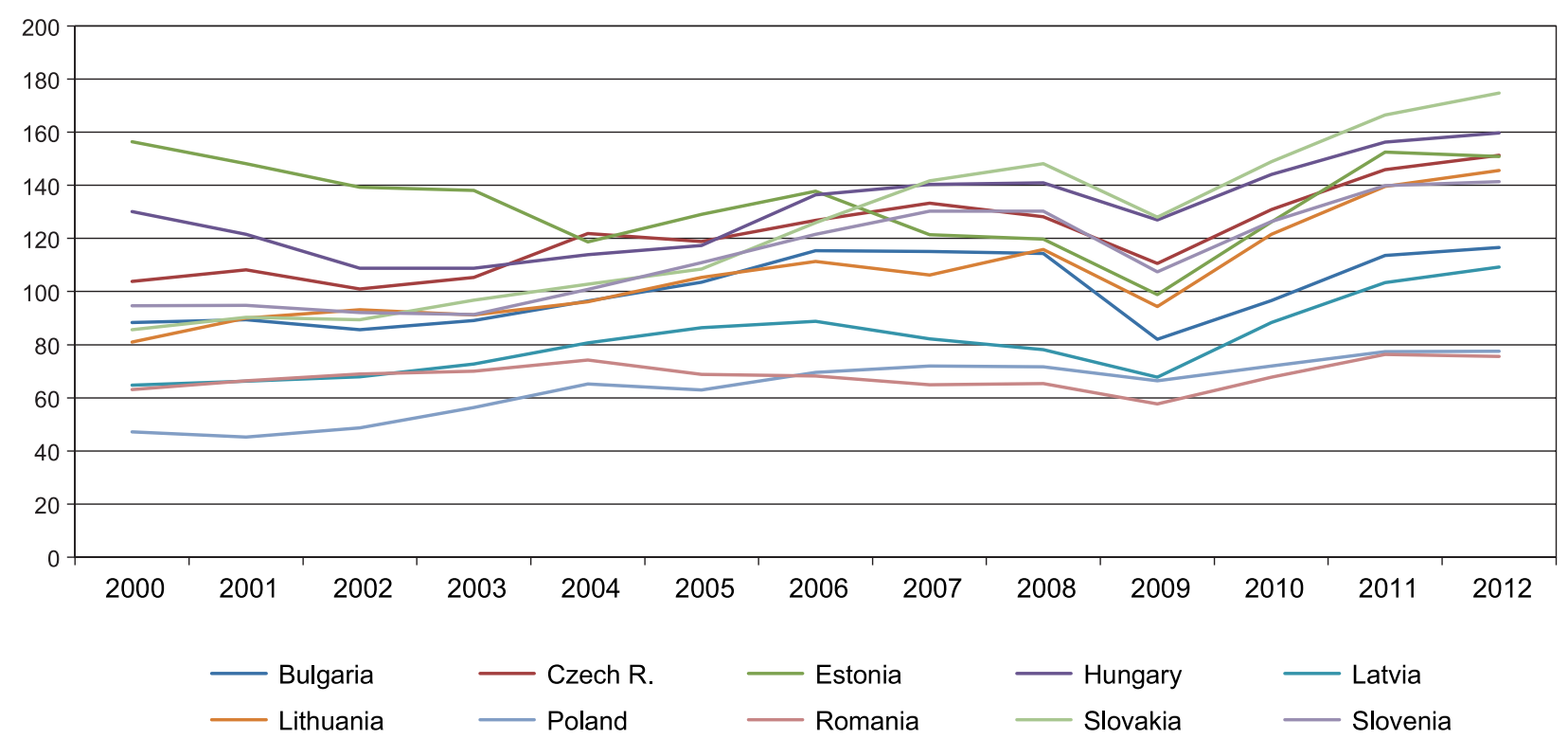

Fig. 3. The current account balance as the share of the GDP, the years 2000-2013 (\%). Source: developed by the authors on the basis of the OECD-WTO data.

contribution to the global imports and exports of commodities was relatively stable, oscillating around $4 \%$. With the same share in global imports and exports (1.1\% in both cases), Poland was the leader among the analysed countries. In the global trade in services, those countries played practically no role at all, accounting for less than $3 \%$ of the world exports and $2.5 \%$ of its imports (Fig. 2). Their position in the EU was much stronger, because their share in its service exports increased every year (in 2012 it was $14.2 \%$ ), and so did their share of its service imports (14.1\% in 2012). Ten years earlier the rates were $8.3 \%$ and $8.7 \%$, respectively (Eurostat, 2014).

With foreign trade volumes shrinking because of the economic crisis rolling across the world, the current accounts in the post-communist countries deteriorated and their proportion of the national GDPs decreased. A particularly steep decline in the value of the latter indicator was noted in Estonia in 2007. In the first years of the crisis, the indicator decreased much more in the post-communist countries than in the eurozone. The countries started to gradually regain their position in international trade after 2009 (Fig. 3).

The European Union continues to be the main trading partner of the new member states, accounting for an average of over $70 \%$ of their trade volume. In 2012, Slovakia had the highest ratio between exports to the EU and total commodity and service exports (Misala 2007). For Estonia, the
EU was the main source of imports (Table 1). The major trading partner for most of the analysed countries was Germany. The only countries for which Germany was not the primary export market in 2012 were Latvia and Lithuania. Germany was also the key supplier of imports used in the new member states. The countries' strong concentration on the EU markets implies relatively low volumes of their trade with non-EU states, the most important of which was Russia, the main trading partner of Lithuania and Latvia. Let us note, however, that for the post-communist countries Russia is a source of fuels rather than an export market. A worrying trend is that those countries tend to focus their trading strategies

Table 1. Trade of the post-communist countries with the EU as the share of their foreign trade volume in $2012(\%)$

\begin{tabular}{|l|c|c|}
\hline \multicolumn{1}{|c|}{ Country } & Exports & Imports \\
\hline Bulgaria & 58.4 & 60.6 \\
\hline Czech Republic & 80.9 & 75.1 \\
\hline Estonia & 66.0 & 80.0 \\
\hline Lithuania & 60.5 & 56.8 \\
\hline Latvia & 63.5 & 78.1 \\
\hline Poland & 75.7 & 74.7 \\
\hline Romania & 70.2 & 73.5 \\
\hline Slovakia & 83.9 & 74.0 \\
\hline Slovenia & 68.8 & 67.2 \\
\hline Hungary & 75.8 & 70.2 \\
\hline
\end{tabular}

Source: developed by the authors on the basis of the Eurostat data. 
on the EU-15, completely omitting new poles of growth available in the global economy, or using them to a limited degree (Liberska 2013).

\section{Selected indicators of changes in the structure of foreign trade in the post-communist countries}

To investigate the geographical concentration of the exports and imports of the post-communist countries, the Herfindahl-Hirschman index $(\mathrm{HHI})^{8}$ was adopted. The geographical concentration of exports was found to be falling, an indication of a growing similarity between the EU-15 and those countries. Between 2000 and 2012, all of them made efforts to enter new export markets in order to increase their diversity. The process was particularly marked in Poland and the Czech Republic (Table 2). In 2000, both countries exported mainly to Germany (35.5\% and $40.5 \%$ of their total exports, respectively), the shares of other countries being below 10\%. By 2012, Polish exports to Germany fell below 25\% of their total volume and the Czech Republic's dependence on the German market dropped to 31.4\% (World Bank 2014). Like the EU-15 states, most post-communist countries tried to add new import markets to those they already used. The exceptions were Lithuania and Latvia, where the concentration of import markets slightly increased. A particularly strong reliance on Russian supplies was observed for many years in Lithuania, which derives almost $1 / 3$ of its imports from this country.

The post-communist countries differ in their structures of foreign commodity trade, the reason being differences between their economies and, to some degree, the different activity of multinational corporations in those countries that assigned them the role of providers of less expensive substitutes of products made in the developed countries (UNIDO 2011). A relevant illustration of the degree to which the structures

\footnotetext{
The HH index allows evaluating the geographical concentration of a country's exports. If all exports go to one market, its value is 1 . If exports are more or less evenly distributed among several markets, its value is close to zero. In practice, it is assumed that a rate of between 0.15 and 0.25 denotes an average concentration of exports; for a rate above 0.25 the concentration is high.
}

of their exports differ is machinery and transport equipment. In the Czech Republic and Hungary, it accounted for over half of exports, but in Bulgaria and Lithuania its rate was below $20 \%$. All the countries kept gradually replacing labour-intensive and low-processed exports with products that were more advanced technologically and needed more capital to be made. In almost all of them, the share of apparel and textile exports markedly decreased between 2000 and 2012. Agricultural products, including food, continued to be an important export item, though. Its importance even increased, particularly in Lithuania and Bulgaria. The export share of machinery and transport equipment, mainly of products delivered by the automotive industry, kept growing, but at a slower rate than in the 1990s9. The slowdown was probably caused by increasing exports of other groups of products and by the falling activity of multinational corporations in the fields of economy comprising the automotive sector. The exports of telecommunications equipment also increased (Slovenia being the only country where they decreased in proportion to total exports), as well as the exports of integrated circuits and electronic components (Table 3). The main driver of changes in the structures of exports in the post-communist countries was variations in their revealed comparative advantages.

The commodity export structure in the post-communist countries and its evolution in the recent years have been determined by referring to their specialisations in international exports. The best way of establishing a country's comparative advantage in the export of some group of products is to calculate the index of its international specialisation. In this study, the revealed comparative advantage was used to this end (Balassa 1965). Its analysis showed that between 2000 and 2012 the post-communist countries were losing their comparative advantages in the export of low-processed products (mainly iron and steel, fuels, mining products, textiles and clothing) in favour of more advanced exports and agricultural products, including food. Most countries improved their comparative advantage

\footnotetext{
9 Between 1995 and 2000, the share of machinery and transport equipment markedly increased, mainly because of the inflow of foreign direct investments to machinery and automotive products (NBP 2014).
} 
Table 2. Export and import concentration indices for the post-communist countries and the EU, 2000 and 2012.

\begin{tabular}{|l|l|l|l|l|}
\hline \multirow{2}{*}{} & \multicolumn{2}{|c|}{ Exports } & \multicolumn{2}{c|}{ Imports } \\
\cline { 2 - 5 } & 2000 & 2012 & 2000 & 012 \\
\hline Bulgaria & 0.06 & 0.05 & 0.100 & 0.072 \\
\hline Czech Republic & 0.18 & 0.11 & 0.127 & 0.098 \\
\hline Estonia & 0.10 & 0.07 & 0.121 & 0.137 \\
\hline Lithuania & 0.06 & 0.05 & 0.112 & 0.085 \\
\hline Latvia & 0.07 & 0.06 & 0.071 & 0.085 \\
\hline Poland & 0.15 & 0.08 & 0.091 & 0.069 \\
\hline Romania & 0.09 & 0.07 & 0.078 & 0.076 \\
\hline Slovakia & 0.12 & 0.08 & 0.091 & 0.085 \\
\hline Slovenia & 0.12 & 0.08 & 0.125 & 0.092 \\
\hline Hungary & 0.13 & 0.09 & 0.095 & 0.067 \\
\hline EU & 0.099 & 0.059 & 0.074 & \\
\hline
\end{tabular}

Concentrations were calculated with the $\mathrm{HH}$ index for the particular member states.

Source: calculated by the authors on the basis of the World Integrated Trade Solution data, the World Bank.

Table 3. Changes in the commodity structure of exports in the post-communist countries from 2000 to 2012.

\begin{tabular}{|c|c|c|c|c|c|c|c|c|c|c|c|}
\hline & $\begin{array}{l}\text { Bul- } \\
\text { garia }\end{array}$ & $\begin{array}{c}\text { Czech } \\
\text { Re- } \\
\text { public }\end{array}$ & $\begin{array}{l}\text { Esto- } \\
\text { nia }\end{array}$ & $\begin{array}{l}\text { Lithu- } \\
\text { ania }\end{array}$ & Latvia & $\begin{array}{l}\text { Po- } \\
\text { land }\end{array}$ & $\begin{array}{l}\text { Roma- } \\
\text { nia }\end{array}$ & $\begin{array}{l}\text { Slova- } \\
\text { kia }\end{array}$ & $\begin{array}{l}\text { Slove- } \\
\text { nia }\end{array}$ & $\begin{array}{l}\text { Hun- } \\
\text { gary }\end{array}$ & $\begin{array}{l}\text { aver- } \\
\text { age }\end{array}$ \\
\hline & \multicolumn{11}{|c|}{$\%$} \\
\hline Agricultural products & 34.9 & -7.6 & 7.5 & 32.9 & -16.5 & 34.7 & 41.3 & 29.6 & 63.5 & 23.0 & 24.3 \\
\hline Food & 58.2 & 12.2 & 89.8 & 71.2 & 250.9 & 48.8 & 180.6 & 84.4 & 67.6 & 26.3 & 89.0 \\
\hline $\begin{array}{l}\text { Fuels and mining } \\
\text { products }\end{array}$ & 38.5 & 24.5 & 284.8 & 16.4 & 30.6 & -3.0 & -34.2 & -12.5 & 112.5 & 47.5 & 50.5 \\
\hline - Fuels & 41.9 & 25.8 & 818.8 & 19.2 & 200.0 & -3.9 & -19.4 & -15.7 & 816.7 & 135.3 & 201.9 \\
\hline Manufactures & -14.6 & -1.5 & 2.9 & -2.2 & 5.2 & -5.5 & 2.2 & 2.3 & -9.7 & -3.0 & -2.4 \\
\hline - Iron and steel & -63.6 & -16.7 & 240.0 & 120.0 & 9.7 & -14.7 & -38.5 & -38.7 & 35.5 & 7.7 & 24.1 \\
\hline Chemicals & -17.0 & -15.5 & 90.9 & 57.1 & 15.6 & 32.4 & 13.8 & -44.2 & 44.5 & 64.6 & 24.2 \\
\hline Pharmaceuticals & 61.1 & 57.1 & -33.3 & 40.0 & -17.2 & 160.0 & 900.0 & -16.7 & 82.6 & 261.5 & 149.5 \\
\hline $\begin{array}{l}\text { Machinery and trans- } \\
\text { port equipment }\end{array}$ & 74.0 & 21.3 & 1.2 & 14.8 & 180.3 & 8.5 & 113.2 & 39.9 & -0.6 & -9.5 & 44.3 \\
\hline $\begin{array}{l}\text { - Office and telecom } \\
\text { equipment }\end{array}$ & 157.1 & 236.4 & -52.2 & -50.0 & 522.2 & 72.5 & -4.0 & 445.2 & 10.5 & -33.5 & 130.4 \\
\hline $\begin{array}{l}\text { - EDP and office } \\
\text { equipment }\end{array}$ & 66.7 & 361.1 & 0.0 & 150.0 & 200.0 & 566.7 & -46.2 & 90.0 & 0.0 & -71.9 & 131.6 \\
\hline $\begin{array}{l}\text { - Telecommunications } \\
\text { equipment }\end{array}$ & 300.0 & 173.7 & -54.5 & 30.0 & 950.0 & 65.5 & 15.2 & 880.0 & -6.3 & 12.0 & 236.6 \\
\hline $\begin{array}{l}\text { - Integrated circuits } \\
\text { and electronic com- } \\
\text { ponents }\end{array}$ & 400.0 & 50.0 & 100.0 & -96.9 & 0.0 & -75.0 & -40.0 & -50.0 & 200.0 & 28.6 & 51.7 \\
\hline Transport equipment & 300.0 & 10.4 & 172.7 & 15.5 & 286.7 & -7.7 & 218.9 & 15.7 & 12.6 & 2.1 & 102.7 \\
\hline - Automotive products & 333.3 & 13.0 & 121.4 & 108.7 & 600.0 & 0.0 & 584.2 & 21.7 & 17.1 & -7.7 & 179.2 \\
\hline Textiles & -40.0 & -61.9 & -81.0 & -59.1 & -67.9 & -57.7 & 5.3 & -63.0 & -30.3 & -38.5 & -49.4 \\
\hline - Clothing & -58.9 & -59.1 & -64.2 & -79.4 & -69.1 & -66.7 & -74.1 & -60.5 & -81.8 & -84.1 & -69.8 \\
\hline
\end{tabular}

The grey colour marks commodity groups that increased their share in the commodity structure in at least 7 of the 10 analysed countries.

Source: calculated by the authors on the basis of the WTO data. 
Table 4. The structure of exports in the post-communist countries in 2012.

\begin{tabular}{|c|c|c|c|c|c|c|c|c|c|c|}
\hline \multirow[t]{2}{*}{ Group of commodities } & $\begin{array}{l}\text { Bulga- } \\
\text { ria }\end{array}$ & $\begin{array}{c}\text { Czech } \\
\text { Repub- } \\
\text { lic }\end{array}$ & $\begin{array}{l}\text { Esto- } \\
\text { nia }\end{array}$ & $\begin{array}{l}\text { Lithu- } \\
\text { ania }\end{array}$ & Latvia & Poland & $\begin{array}{l}\text { Roma- } \\
\text { nia }\end{array}$ & $\begin{array}{l}\text { Slova- } \\
\text { kia }\end{array}$ & $\begin{array}{l}\text { Slove- } \\
\text { nia }\end{array}$ & $\begin{array}{l}\text { Hun- } \\
\text { gary }\end{array}$ \\
\hline & \multicolumn{10}{|c|}{$\%$} \\
\hline Agricultural products & 17.0 & 6.1 & 14.4 & 20.2 & 29.8 & 13.2 & 11.3 & 7.0 & 8.5 & 10.7 \\
\hline - Food & 15.5 & 4.6 & 9.3 & 17.8 & 20.0 & 11.9 & 8.7 & 5.9 & 6.2 & 9.6 \\
\hline Fuels and mining products & 33.8 & 6.1 & 17.7 & 26.3 & 11.1 & 9.7 & 9.6 & 9.1 & 10.2 & 5.9 \\
\hline - Fuels & 16.6 & 3.9 & 14.7 & 24.8 & 7.5 & 4.9 & 5.8 & 5.9 & 5.5 & 4.0 \\
\hline Manufactures & 48.4 & 86.8 & 66.9 & 53.5 & 58.4 & 75.7 & 78.4 & 84.8 & 81.0 & 83.5 \\
\hline - Iron and steel & 2.8 & 3.5 & 1.7 & 1.1 & 6.8 & 2.9 & 4.8 & 5.7 & 4.2 & 1.4 \\
\hline - Chemicals & 8.3 & 6.0 & 6.3 & 13.2 & 7.4 & 9.0 & 6.6 & 4.3 & 15.9 & 10.7 \\
\hline Pharmaceuticals & 2.9 & 1.1 & 0.4 & 1.4 & 2.4 & 1.3 & 2.0 & 0.5 & 8.4 & 4.7 \\
\hline $\begin{array}{l}\text { Machinery and transport } \\
\text { equipment }\end{array}$ & 16.7 & 54.0 & 33.6 & 17.8 & 19.9 & 37.1 & 40.3 & 55.0 & 35.7 & 53.5 \\
\hline $\begin{array}{l}\text { Office and telecom equip- } \\
\text { ment }\end{array}$ & 1.8 & 14.8 & 11.9 & 2.3 & 5.6 & 6.9 & 4.8 & 16.9 & 2.1 & 16.9 \\
\hline - EDP and office equipment & 0.5 & 8.3 & 0.3 & 1.0 & 1.2 & 2.0 & 0.7 & 1.9 & 0.3 & 3.9 \\
\hline $\begin{array}{l}\text { - Telecommunications } \\
\text { equipment }\end{array}$ & 0.8 & 5.2 & 11.1 & 1.3 & 4.2 & 4.8 & 3.8 & 14.7 & 1.5 & 12.1 \\
\hline $\begin{array}{l}\text { - Integrated circuits and } \\
\text { electronic components }\end{array}$ & 0.5 & 1.2 & 0.4 & 0.1 & 0.2 & 0.2 & 0.3 & 0.3 & 0.3 & 0.9 \\
\hline Transport equipment & 3.2 & 20.2 & 6.0 & 6.7 & 5.8 & 16.8 & 16.9 & 25.8 & 16.1 & 19.2 \\
\hline - Automotive products & 1.3 & 18.2 & 3.1 & 4.8 & 3.5 & 12.6 & 13.0 & 24.7 & 14.4 & 15.6 \\
\hline Textiles & 1.5 & 1.6 & 0.8 & 1.8 & 1.8 & 1.1 & 2.0 & 1.0 & 2.3 & 0.8 \\
\hline - Clothing & 6.0 & 0.9 & 1.9 & 2.6 & 2.9 & 2.0 & 5.8 & 1.7 & 0.8 & 0.7 \\
\hline
\end{tabular}

Commodity groups in which countries had revealed comparative advantage are marked in bold.

in the export of EDP and office equipment and of the automotive industry's products. As far as other groups of products are concerned, the revealed comparative advantages were specific to a country. In 2012, almost all countries (except for Slovakia, Slovenia and the Czech Republic) specialised in international trade in agricultural products, including food. Bulgaria and Lithuania were the only ones that had a relative comparative advantage in the export of fuels and mining products. Almost all post-communist countries (with the exception of Estonia, Lithuania and Hungary) specialised in the export of iron and steel, but only a few specialised in the export of chemical products (Lithuania and Slovenia) as well as EDP and office equipment (the Czech Republic). None of them showed advantages in the export of integrated circuits and electronic components. The Czech Republic, Poland, Romania, Slovenia and Hungary specialised in the export of transport equipment, including automotive products. In 2012, Hungary, Romania and the Czech Republic had the greatest number of specialisations in the export of the analysed groups of products. Poland had a comparative advantage in agricultural products, including food, as well as in iron and steel, as well as machinery and transport equipment (mainly automotive products; Table 5).

The structure of exports in the post-communist countries still suffers from a low share of hightech products. This opinion can be formulated even though it has not been resolved yet whether high-tech exports of developing countries can really serve as a reliable indication of their technological development (Mani 2000, Srholec 2005). Why it may not be so is usually explained by the fact that a country's high-tech exports may result from its position in global value chains determined by its revealed comparative advantages (so-called vertical specialisation) ${ }^{10}$ rather than by its innovative activity. In 2012, the post-communist countries had one of the lowest values of the summary innovation index. Slovenia, Estonia and the Czech Republic were ranked the highest in that respect, but not high enough to reach the EU average (UNU-MERIT 2013). This situation

10 Global value chains are discussed at greater length below. 


\begin{tabular}{|c|c|c|c|c|c|c|c|c|c|c|c|c|c|c|c|c|c|c|}
\hline 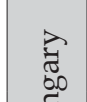 & 穴 & 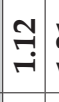 & זָּ & & $\begin{array}{c}\text { त. } \\
\end{array}$ & & & نـ & نْم & مִ & & & ભె & $\vec{i}$ & 8 & & & \multirow{21}{*}{ 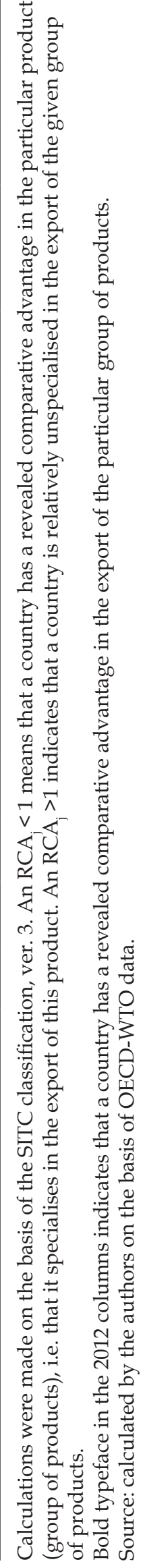 } \\
\hline 壱 & $\begin{array}{l}8 \\
\text { ¿े } \\
\end{array}$ & م̂. & $\begin{array}{l}\infty \\
\stackrel{\infty}{+} \\
+\end{array}$ & & & & & ? & ले & & $\vec{c}$ & & $\stackrel{10}{\stackrel{2}{0}}$ & & $\stackrel{\vec{\infty}}{\sim}$ & & & \\
\hline 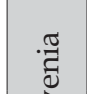 & त्: & $\begin{array}{l}\infty \\
\infty \\
0\end{array}$ & 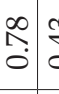 & $\stackrel{8}{8}$ & \begin{tabular}{c}
$\overbrace{}^{\infty}$ \\
\hdashline
\end{tabular} & & & id & $\stackrel{\infty}{\stackrel{\infty}{r}}$ & స̃ & ·. & & 궁 & & హ. & & & \\
\hline$\frac{\vec{b}}{\omega}$ & ठి & 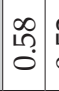 & 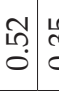 & & & & & 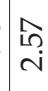 & $\begin{array}{l}\infty \\
\infty \\
0 \\
0\end{array}$ & & 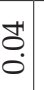 & & $\stackrel{1}{O}$ & & 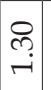 & & & \\
\hline$\frac{\sqrt{\frac{\pi}{\sigma}}}{\text { ब }}$ & $\begin{array}{l}\text { Iี } \\
\text { ते }\end{array}$ & $\begin{array}{c}\mathrm{N} \\
\mathrm{O}\end{array}$ & $\begin{array}{c}n \\
0 \\
0\end{array}$ & & & & & $\stackrel{\circ}{\circ}$ & ث্ & $\stackrel{+}{\stackrel{2}{-}}$ & 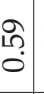 & & 궁 & & 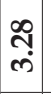 & & & \\
\hline$\frac{b}{w}$ & ¿ి & : & 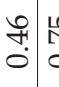 & & & & & & ô & ત્ઞ & $\begin{array}{l}0 \\
\stackrel{7}{0}\end{array}$ & & & 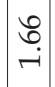 & $\stackrel{\vec{\lambda}}{\vec{\lambda}}$ & & & \\
\hline : & $\begin{array}{l}\mathcal{N} \\
\stackrel{\sim}{\sim}\end{array}$ & $\underset{7}{\stackrel{9}{7}}$ & 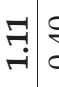 & & & & & & సָ & $\mid \begin{array}{c}0 \\
10 \\
0\end{array}$ & $\begin{array}{l}\text { స్. } \\
0\end{array}$ & & $\stackrel{ }{\circ}$ & & 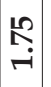 & & & \\
\hline 气ี & $\begin{array}{l}8 \\
\text { ڤેे }\end{array}$ & $\begin{array}{c}\infty \\
\infty \\
\dot{0}\end{array}$ & 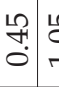 & & & & & $\stackrel{2}{\circ}$ & 芯 & $\begin{array}{c}\tilde{c} \\
\tilde{o} \\
\stackrel{2}{2}\end{array}$ & $\begin{array}{c}\overrightarrow{ } \\
\vdots\end{array}$ & & & $\begin{array}{c}0 \\
\grave{0}\end{array}$ & ஸे & & 6 & \\
\hline छ్ & 苂 & $\underset{f}{\stackrel{f}{r}}$ & 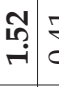 & 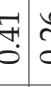 & & & & I! & $\stackrel{m}{\stackrel{9}{-}}$ & $\begin{array}{l}\Omega \\
\hat{O} \\
0\end{array}$ & 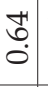 & & 8 & & $\underset{r}{\Gamma}$ & $\infty$ & & \\
\hline & $\begin{array}{l}8 \\
\stackrel{్}{1}\end{array}$ & 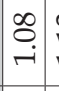 & $\stackrel{\rightarrow}{\rightarrow}$ & $\hat{\sigma}_{0}$ & $\stackrel{5}{0}$ & تُ & & 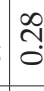 & $\begin{array}{l}\mathfrak{\imath} \\
0\end{array}$ & 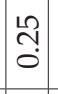 & \begin{tabular}{l} 
: \\
\hdashline \\
\hdashline
\end{tabular} & & & & $\begin{array}{c}\infty \\
\stackrel{\infty}{r} \\
\end{array}$ & & & \\
\hline : డ్ర్ & $\begin{array}{l}\text { Iี } \\
\text { ते }\end{array}$ & $\vec{i}$ & $\begin{array}{c}\text { స̦ } \\
\text { त }\end{array}$ & 8 & $\hat{\mathrm{N}}$ & s. & \begin{tabular}{c|c}
$\infty$ \\
0 \\
\hdashline
\end{tabular} & fㅇㅇ & 㿻 & స̃ & लె. & & & $\mid \begin{array}{c}0 \\
\text { ț. } \\
0\end{array}$ & ț & & & \\
\hline 声 & 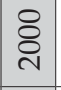 & $\begin{array}{c}\infty \\
\infty \\
\sim \\
-1\end{array}$ & 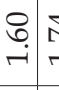 & $\stackrel{+}{H}$ & $\begin{array}{ll}\infty \\
i \\
ن\end{array}$ & & & 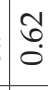 & ले. & $\stackrel{\vec{m}}{0}$ & $\begin{array}{l}\stackrel{0}{0} \\
0 \\
0\end{array}$ & & & $\begin{array}{l}0 \\
\vdots \\
0\end{array}$ & సి & & & \\
\hline$\frac{\pi}{5}$ & సี & $\begin{array}{l}\overrightarrow{1} \\
\dot{m}\end{array}$ & 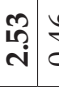 & $\begin{array}{ll}\stackrel{2}{1} \\
0\end{array}$ & $\begin{array}{c}\text { હે } \\
\text { cे }\end{array}$ & & 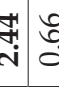 & 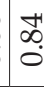 & $\stackrel{0}{0}$ & $\begin{array}{c}\stackrel{0}{10} \\
0 \\
0\end{array}$ & ले & & 웅. & กิ & f̊ & & & \\
\hline 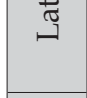 & ৪ి & 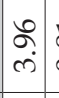 & \begin{tabular}{c|c}
$\overrightarrow{0}$ \\
0 \\
0
\end{tabular} & ¿ֶ. & ડ્તి & \begin{tabular}{c}
1 \\
$\dot{5}$ \\
\hdashline
\end{tabular} & & $\stackrel{8}{S}$ & 궁 & 号 & 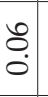 & & & & 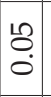 & & & \\
\hline . & 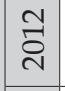 & ஸิ & 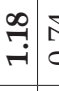 & & & & & & $\underset{\text { ¿े }}{\mathrm{r}}$ & $\underset{\sim}{\stackrel{\sim}{*}}$ & $?$ & & & ณ̊? & $\underset{7}{\ddagger}$ & $\theta$ & 0 & \\
\hline 荀 & ষి & $\stackrel{2}{\curvearrowright}$ & 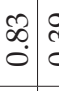 & ले & $\varepsilon$ & Pُ & & ले & જ̊ & 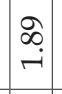 & 0 & & 0 & & $\stackrel{\infty}{\stackrel{\infty}{0}}$ & & & \\
\hline 氜 $\frac{}{3}$ & సี & $\begin{array}{l}0 \\
0 \\
0\end{array}$ & 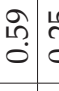 & & & & & & - & & $\begin{array}{l}? \\
\mathbf{i} \\
\end{array}$ & & & ָૃ & $\begin{array}{l}\mathrm{L} \\
\mathrm{i} \\
\end{array}$ & & 0 & \\
\hline & ষ্ণ & $\begin{array}{c}\mathcal{R} \\
\hat{O}\end{array}$ & 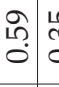 & & & - & & & 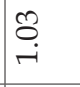 & 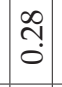 & $\circ$ & & $\stackrel{0}{0}$ & & 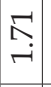 & & & \\
\hline . & तี & 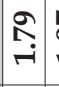 & 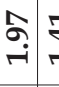 & F & & & & & 둥 & $\underset{\mathfrak{0}}{\stackrel{0}{0}}$ & & & 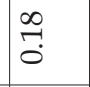 & & $\begin{array}{l}\infty \\
\stackrel{0}{0} \\
\end{array}$ & & & \\
\hline 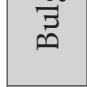 & ષ્ટ & $\begin{array}{c}\infty \\
+ \\
+ \\
\sim\end{array}$ & 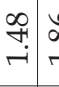 & & & & & $P$ P & స̃ & 우 & & & $0^{\circ}$ & & $\begin{array}{c}0 \\
0 \\
0\end{array}$ & & & \\
\hline & & 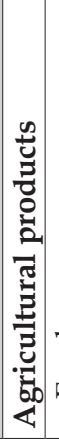 & $\begin{array}{c}\vec{z} \\
0 \\
0 \\
0 \\
1 \\
1\end{array}$ & 5 & & & 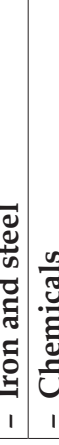 & & 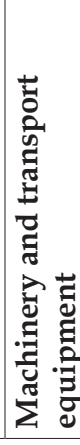 & 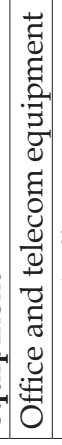 & & 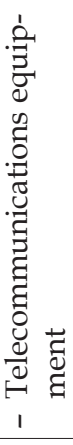 & 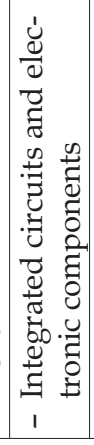 & 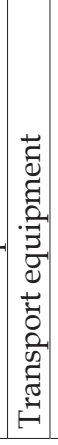 & 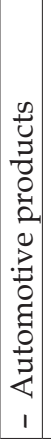 & & & \\
\hline
\end{tabular}




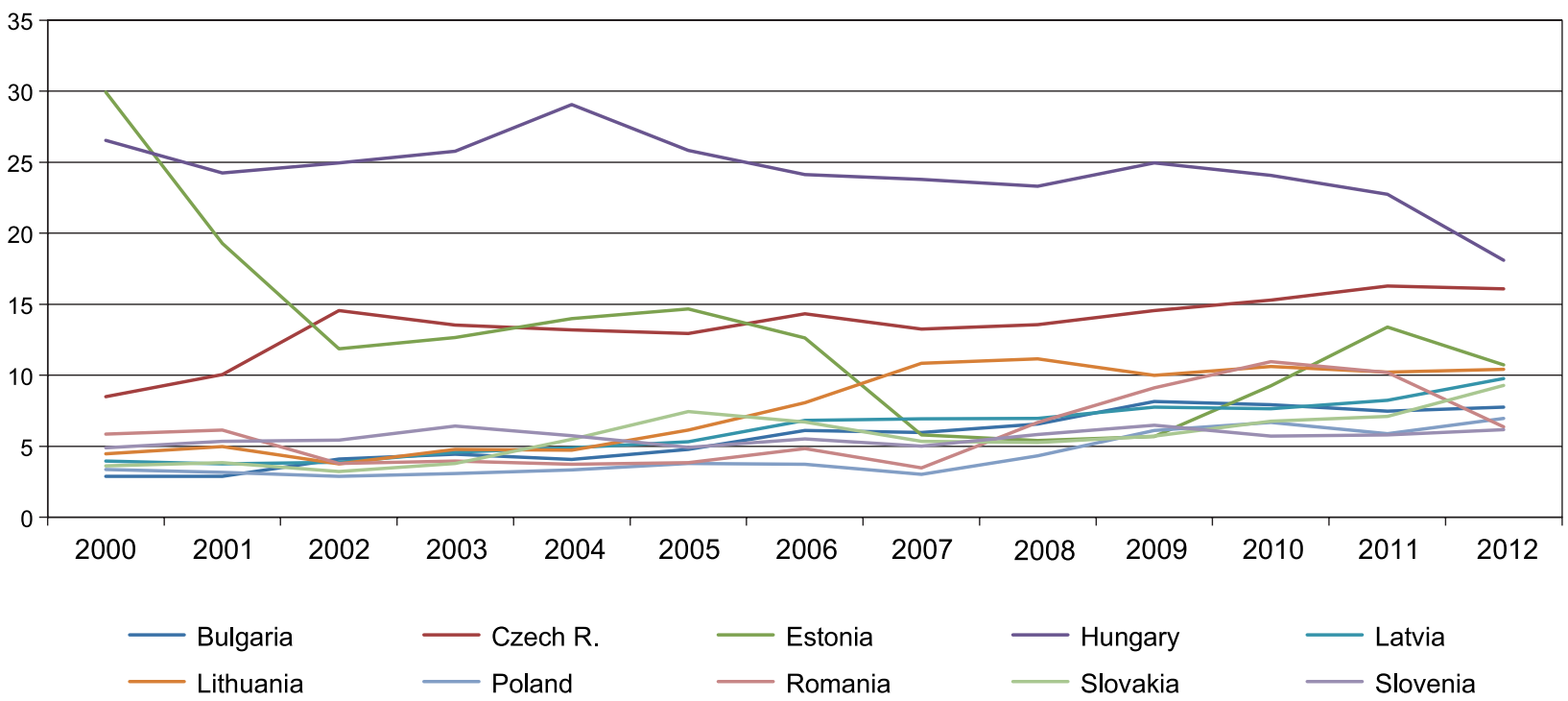

Fig. 4. High-tech products' share in post-communist countries' industrial exports, 2000-2012. Source: developed by the authors on the basis of the World Development Indicators data, the World Bank.

points to a relatively low level of technological advancement in the analysed countries, probably caused by small expenditures on $R \& D$ relative to the GDP in many of them. In 2012, Estonia and Slovenia had the ratios of $R \& D$ expenditure to the GDP of $2.38 \%$ and $2.47 \%$, respectively, and were the only post-communist countries where they exceeded the EU-27 average of $2.03 \%$. The Czech Republic was close to it (1.84\%). Between 2001 and 2011, R\&D outlays grew the fastest in Estonia, with more than half of them contributed by the enterprise sector. Other countries, including Poland with a ratio of $0.77 \%$, were much below the EU average. Slovenia and Estonia had also the highest employment in the R\&D sector, the rates of which surpassed the EU average. The amount of R\&D expenditure and the size of $R \& D$ personnel have a direct effect on the number of high-tech patent applications registered in a country. Estonia and Slovenia were the leaders again, with 3 and 2.1 patent applications, respectively, per million population. Hungary had a rate of 2.1, too, mainly because of the strong patent activity of international corporations in

Table 6. Summary measures of the commodity concentration of exports and imports in the post-communist countries and the EU in 2000 and 2012.

\begin{tabular}{|l|c|c|c|c|c|c|c|c|}
\hline \multirow{2}{*}{} & \multicolumn{4}{|c|}{ Export } & \multicolumn{4}{c|}{ Import } \\
\cline { 2 - 9 } & \multicolumn{2}{|c|}{ Gini coefficient } & \multicolumn{2}{c|}{ HH index } & \multicolumn{2}{c|}{ Gini coefficient } & \multicolumn{2}{c|}{ HH index } \\
\cline { 2 - 9 } & 2000 & 2012 & 2000 & 2012 & 2000 & 2012 & 2000 & 2012 \\
\hline Bulgaria & 0.5447 & 0.5142 & 0.1170 & 0.1080 & 0.5493 & 0.5134 & 0.1320 & 0.1240 \\
\hline Czech Republic & 0.6008 & 0.6770 & 0.1420 & 0.1940 & 0.5657 & 0.5879 & 0.1500 & 0.1610 \\
\hline Estonia & 0.6084 & 0.5697 & 0.1550 & 0.1310 & 0.5336 & 0.5501 & 0.1560 & 0.1310 \\
\hline Lithuania & 0.5385 & 0.5050 & 0.1170 & 0.1140 & 0.4842 & 0.5551 & 0.1120 & 0.1590 \\
\hline Latvia & 0.7032 & 0.4799 & 0.2100 & 0.0970 & 0.4522 & 0.4784 & 0.1030 & 0.1040 \\
\hline Poland & 0.5199 & 0.5308 & 0.1090 & 0.1180 & 0.5247 & 0.5085 & 0.1270 & 0.1140 \\
\hline Romania & 0.5792 & 0.5545 & 0.1280 & 0.1240 & 0.5077 & 0.5166 & 0.1240 & 0.1240 \\
\hline Slovakia & 0.5831 & 0.6708 & 0.1280 & 0.1840 & 0.5483 & 0.5703 & 0.1270 & 0.1430 \\
\hline Slovenia & 0.5887 & 0.6019 & 0.1250 & 0.1300 & 0.4978 & 0.5092 & 0.1120 & 0.1120 \\
\hline Hungary & 0.6875 & 0.6673 & 0.2810 & 0.2120 & 0.6457 & 0.6386 & 0.2280 & 0.1780 \\
\hline EU & 0.6138 & 0.6156 & 0.1550 & 0.1380 & 0.5539 & 0.5705 & 0.1410 & 0.1480 \\
\hline
\end{tabular}

Calculations made on the basis of a two-digit level of disaggregation according to the HS classification 1988/92. Source: calculated by the authors on the basis of the UN data (2014) and the World Bank data (2014). 


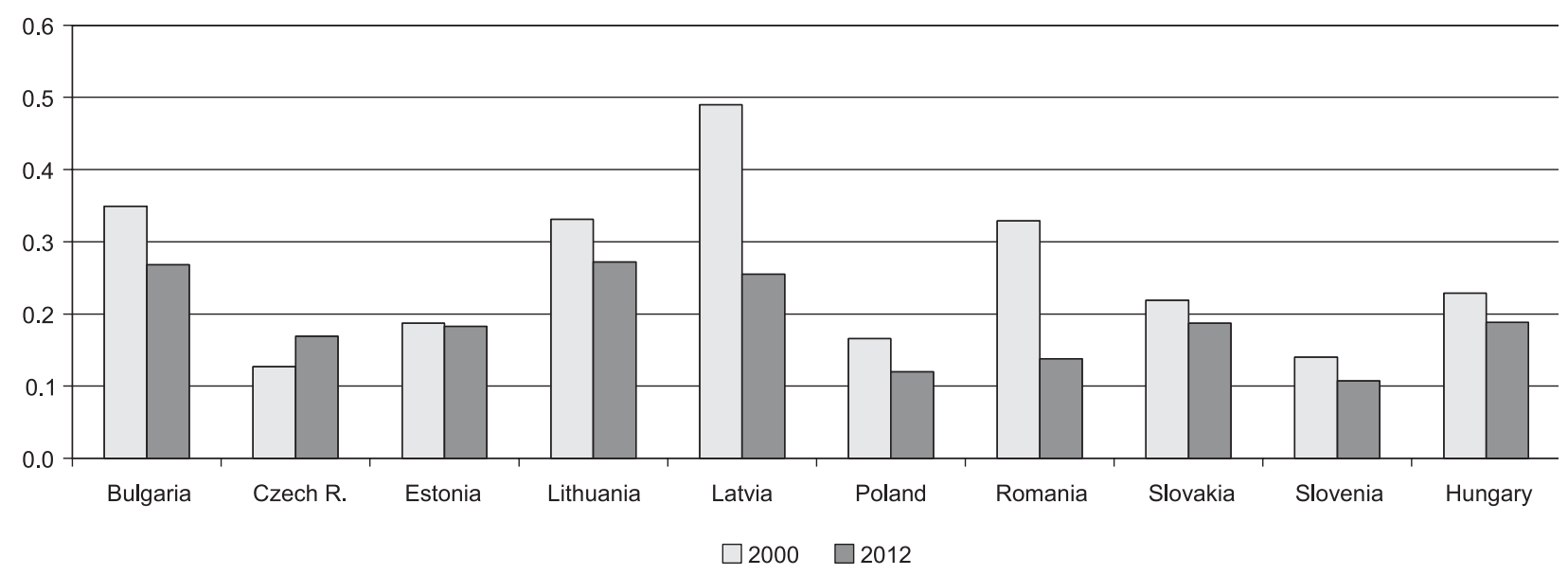

Fig. 5. Indicators of similarity between the commodity export structures of the post-communist countries and the EU-15, 2000 and 2012.

To measure similarity, the Euclidean distance was used. The difference between the export structures of the analysed countries and the EU increases as the Euclidean distance values approach one and decreases when they tend to zero.

Calculations were made on the basis of the first level of disaggregation according to the HS classification 1988/92.

Source: calculated by the authors on the basis of the World Integrated Trade Solution data, the World Bank.

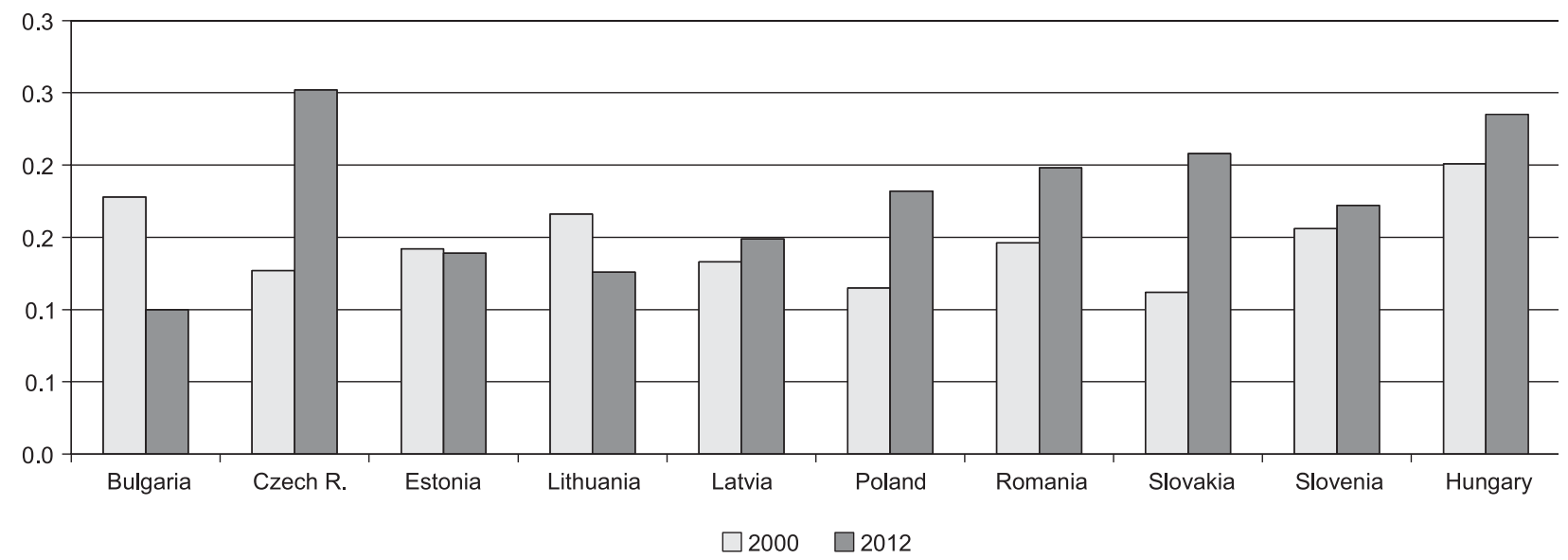

Fig. 6. Indicators of similarity between the commodity import structures of the post-communist countries and the EU-15, 2000 and 2012.

To measure similarity, the Euclidean distance was used. The difference between the import structures of the analysed countries and the EU increases as the Euclidean distance values approach one and decreases when they tend to zero.

Calculations were made on the basis of the first level of disaggregation according to the HS classification 1988/92.

Source: calculated by the authors on the basis of the World Integrated Trade Solution data, the World Bank.

the automotive, electronic and pharmaceutical industries. However, all these rates were far below the EU average of 9.3 applications per million population (Eurostat 2014).

The share of high-tech products in the total volume of industrial exports was the biggest in Hungary (above 18\%). Among the post-communist countries, Hungary and the Czech Republic were the most similar to the developed countries ${ }^{11}$ in this respect. High-tech and medium-tech

$\overline{11}$ For instance, the 2012 share of high-tech exports in industrial production in Germany was even lower products accounted for around $80 \%$ of their industrial output (UNCTAD 2013). They were also the only two countries where in 2012 the share of high-tech products in industrial exports surpassed the EU average (in Poland it was one of the smallest) (Eurostat 2014).

In the last years of the analysed period, the volumes of high-tech exports clearly decreased relative to total exports in Hungary and Estonia

than in Hungary and the Czech Republic (15.8\%). In the USA, the value of the rate was $17.8 \%, 21.7 \%$ in the UK, $17.4 \%$ in Japan, and 25.4\% in France (World Bank 2014). 


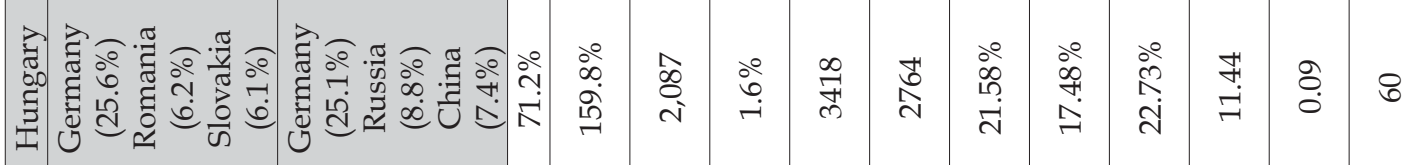

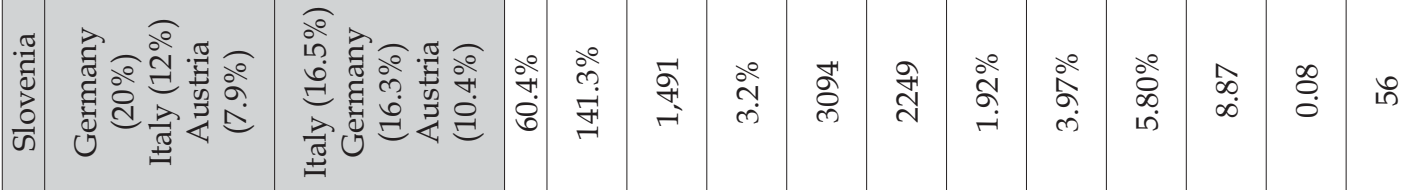

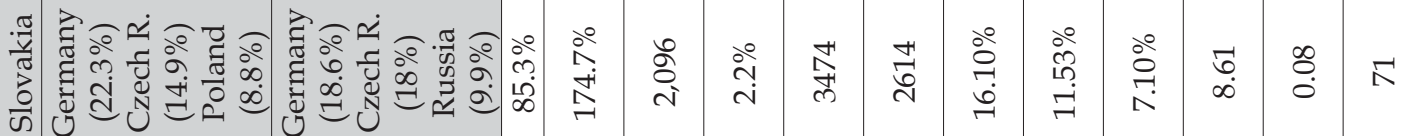

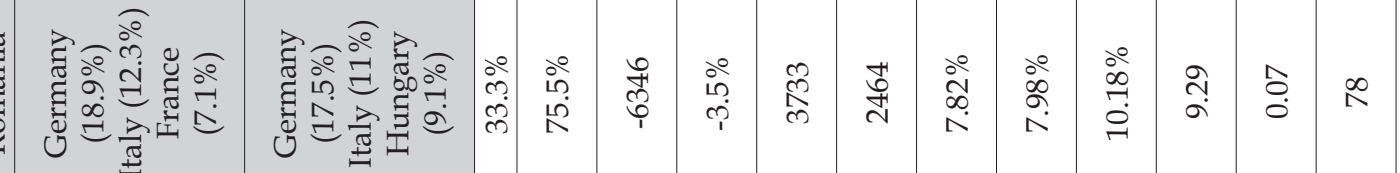

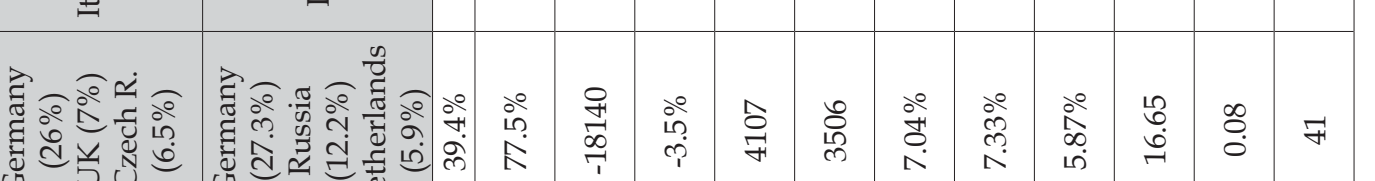

Uु

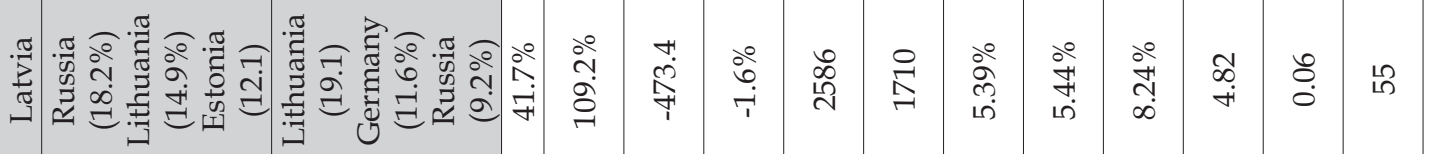

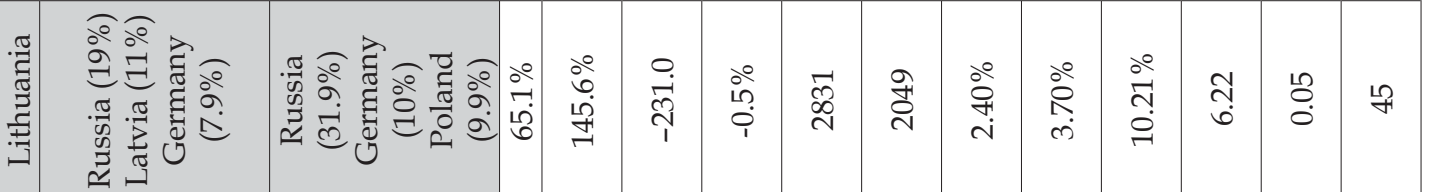

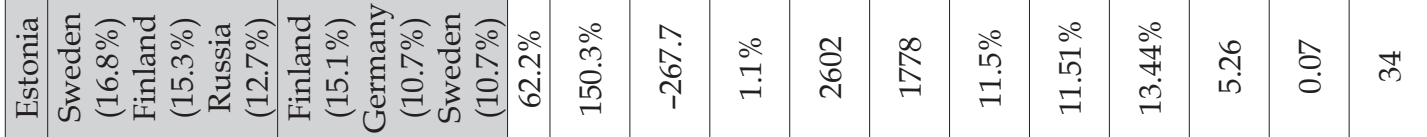

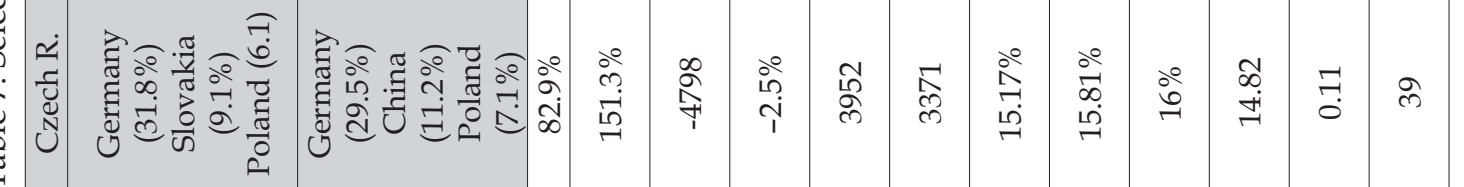

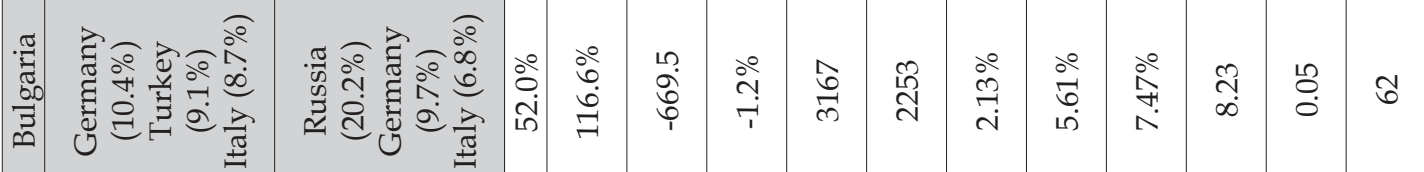

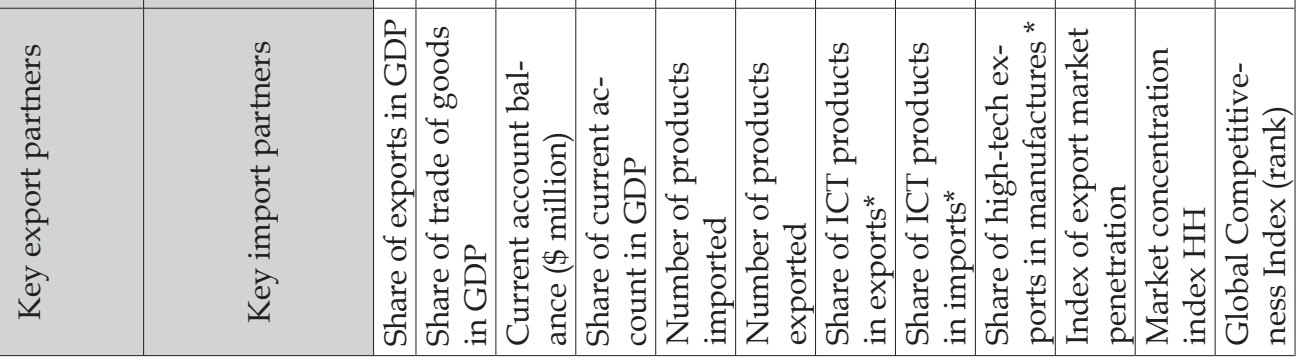


(Fig. 4). The main reason for this was limited export activity of multinational corporations that had to struggle with the global crisis. In both countries, but chiefly in Hungary, the main exporters of high-tech products are international corporations in the automotive and electronic industries (Sass, Kalotay 2012).

The commodity concentration of exports can be analysed using summary measures such as the Gini coefficient or the HH index. Neither of them revealed distinct trends in this area. According to both of them, Bulgaria, Estonia, Lithuania, Latvia, Romania and Hungary diversified the structure of their exports. The process was particularly notable in Latvia, where all groups of products had almost equal shares of exports. The 2000-2012 changes in the commodity concentration of imports of the analysed countries were rather insignificant. The Gini coefficient, like the $\mathrm{HH}$ index, showed that the concentration increased slightly in all the post-communist countries except Bulgaria, Poland and Hungary. In Slovenia and Romania, it remained as it was before 2000. The biggest increase in the commodity concentration of imports was noted in Lithuania (the changes in the Lithuanian $\mathrm{HH}$ index and Gini coefficient are the biggest). Other member states also showed a tendency to concentrate their commodity imports (Table 6).

The similarity between the structure of commodity exports in the post-communist countries and the EU was assessed by the widely used Euclidean distance. Between 2000 and 2012 almost all the analysed countries became more similar to the EU in that respect (an exception being the Czech Republic where the difference between the structures increased slightly). The values of the Euclidean distance for Slovenia and Poland were close to 0.1 , indicating that the export structures of those two countries were particularly similar to that characterising the EU (Fig. 5). As regards the commodity structure of imports, most post-communist countries (except Bulgaria, Estonia and Lithuania) were clearly different from the EU. The Czech Republic and Hungary were the most dissimilar, and Bulgaria resembled the EU the most (Fig. 6). Generally, however, the post-communist countries and the EU can be considered to have similar structures of both exports and imports, because the values of the Euclidean distance are not high in either case.
The increasing similarity between commodity structures stimulated intra-industry trade flows between the post-communist countries and the EU-15. An analysis of indices such as the GrubelLloyd index and of their changes in the last years of the study period shows increased flows in the period following the countries' entry into the European Union. At the same time, the flows were stronger within the countries than between them and the EU-15 ${ }^{12}$.

\section{Conclusions}

The trading rules used by the old EU-15 adapted by the post-communist countries in Europe brought them measurable benefits. It was very crucial, particularly in the first years after their EU accession (Weresa 2014). As a result, the post-communist economies became similar to those in the EU-15 (Iossifov 2014, Halmai, Vasary 2012). We also observe a convergence of their development to the EU-15 (Matkowski et al. 2013). What is more, the increasing integration caused the post-communist markets to join regional value chains. Considering the structure of their trade and links with the EU-15, it is apparent that they became the main trading and investment partners for the European Union. Hence, their integration with the EU structures made their development faster, but also made them more sensitive to industrial and demand shocks coming from the eurozone. It is predicted that the present model is not going to be changed, especially in the context of the participation in production networks. However, it is possible that the processes observed in foreign trade will have a different intensity than today.

\section{References}

Adam A., Kosma T., McHugh J., 2003. Trade-liberalization strategies: What could southeastern Europe learn from CEFTA and BFTA? IMF Working Papers Series.

Balassa B., 1965. Trade liberalisation and "revealed" comparative advantage. The Manchester School of Economics, May: 99-123.

12 The methodology for calculating intra-industry trade indicators is not presented to save space. A very good discussion of this topic can be found, inter alia, in Molendowski (2012). 
Baldwin R., 1994. Towards an integrated Europe. Graduate Institute of International Studies, Geneva.

Baldwin R., 1995. The eastern enlargement of the European Union. European Economic Review 39: 474-481.

Cieślik A., 2012. Wptyw rozwoju społecznego na handel $i$ inwestycje zagraniczne (Effect of social development on trade and foreign investments). PWE, Warszawa.

Cieślik E., 2012. Efekt smoka. Skutki ekspansji gospodarczej Chin po 1978 roku (The dragon effect. Effects of China's economic expansion after 1978). CeDeWu, Warszawa.

Cieślik E., Biegańska, J., Środa-Murawska S., 2016. The intensification of foreign trade in post-socialist countries and their role in global value chains. Acta Oeconomica 66 (2): 467-489. DOI: 10.1556/032.2016.66.2.5

Dangerfield M., 1995. Is there a revival of regional integration in Eastern Europe? European Business Review 95: 4-12.

De Benedictis L., De Santis R., Vicarelli C., 2005. Hub-andspoke or else? Free trade agreements in the 'enlarged' European Union. The European Journal of Comparative Economics 2 (2): 245-260.

Eurostat 2014. [Online] Available at: http://epp.eurostat. ec.europa.eu/portal/page/portal/eurostat/home/

Halmai P., Vasary V., 2012. Convergence crisis: Economic crisis and convergence in the European Union. International Economics and Economic Policy 9: 297-322.

IMF 2014. Data and statistics. [Online] Available at: https:/ / www.imf.org/ external/ data.htm.

Iossifov P., 2014. Cross-border production chains and business cycle co-movement between Central and Eastern European Countries and Euro Area Member States. Working Paper Series, issue 1628, European Central Bank.

Kawecka-Wyrzykowska E., 2009. Polityki gospodarcze Unii Europejskiej (Economic policies of the European Union). Szkoła Główna Handlowa w Warszawie. Oficyna Wydawnicza, Warszawa.

Kersan-Škabić I., 2009. Trade potential of "CEFTA-2006". Our Economy (Nase Gospodarstvo) 55: 42-51.

Liberska B., 2013. Nowe centra wzrostu światowej gospodar$\mathrm{ki}$ (New growth centres of the world economy). Studia Ekonomiczne LLXXVII(2): 191-212.

Mani S., 2000. Exports of high-technology products from developing countries: Is it real or a statistical artefact? UNU/INTECH Discussion Papers.

Marer P., 2010. The global economic crises: Impacts on Eastern Europe. Acta Oeconomica 60 (1): 3-33.

Matkowski Z., Próchniak M., Rapacki R., 2013. Nowe i stare kraje Unii Europejskiej: konwergencja czy dywergencja? (The new and the old EU states: a convergence or a divergence?) Prace i Materiaty Instytutu Rozwoju Gospodarczego SGH 91: 63-98.

Misala J., 2007. Rozwój wspótpracy gospodarczej Polski z nowymi krajami członkowskimi Unii Europejskiej oraz z Rosja, Ukraina i Białorusia (Development of Poland's economic cooperation with the new EU member states and with Russia, Ukraine and Belarus). Wydawnictwo Politechniki Radomskiej, Radom.

Molendowski E., 2009. Liberalizacja wymiany handlowej krajów Europy Środkowo-Wschodniej - jej znaczenie $\mathrm{w}$ procesie integracji europejskiej (Liberalisation of the trade exchange of CEE countries: its significance in the process of European integration). In: Gospodarka świato- wa w warunkach globalizacji i regionalizacji rynków. Difin, Warszawa: 123-167.

Molendowski E., 2012. Integracja handlowa w Nowych Panstwach Członkowskich (Trade integration in the new member states). Difin, Warszawa.

NBP 2014. Sytuacja gospodarcza w krajach Europy Środkowej $i$ Wschodniej (Economic situation in the countries of Central and Eastern Europe). Instytut Ekonomiczny, Warszawa.

OECD 2014. OECD.StatExtracts. [Online] Available at: http://stats.oecd.org_[accessed 29 April 2014].

Sass M., Kalotay K., 2012. Inward FDI in Hungary and its policy context. Vale Columbia Center on Sustainable International Investment, New York.

Sołtysińska A., Czubik P., 1997. CEFTA - Środkowoeuropejska Strefa Wolnego Handlu: komentarz do umowy międzynarodowej wraz z podaniem obecnie obowiazujących między stronami stawek celnych (Central European Free Trade Zone: a comment to the international agreement, with current customs rates). Audytoriat, Kraków.

Sołtysińska A., Czubik P., 1997. CEFTA - Środkowoeuropejska Strefa Wolnego Handlu: komentarz, obecny poziom stawek celnych w handlu pomiędzy stronami CEFTA, przewidywane w najbliższych latach redukcje cet w handlu pomiędzy stronami (Central European Free Trade Zone: a comment, current customs rates among CEFTA partners, anticipated reductions). Zakamycze, Kraków.

Srholec M., 2005. High-tech exports from developing countries: A symptom of technology spurts or statistical illusion. TIK Working Papers, University of Oslo.

Synowiec E., 2004. Funkcjonowanie rynku wewnętrznego (Operation of an internal market). In: Kawecka-Wyrzykowska E., Synowiec E. (eds), Unia Europejska. IKCHZ, Warszawa: 72-73.

Świerkocki J., 2004. Integracja środkowoeuropejska (Central European integration). In: Integracja europejska. PWE, Warszawa: 429-430.

Tymoczko I., 2013. Analiza porównawcza systemów kursu walutowego (Comparative analysis of systems of currency exchange rates). Materiaty i Studia NBP 287, Warszawa.

UNCTAD 2013. World investment report 2013. UNCTAD, Geneva.

UNIDO 2011. Mapping global value chain: Intermediate goods trade and structural change in the world economy. Development Policy and Strategic Research Branch, Vienna.

United Nations 2014. UN Comtrade. [Online] Available at: http://comtrade.un.org/[accessed 29 April 2014].

UNU-MERIT 2013. Innovation Union Scoreboard 2013. European Commission.

Weresa M., 2014. Dekada członkostwa Polski w Unii Europejskiej (The decade of Poland's EU membership). Instytut Gospodarki Światowej, Szkoła Główna Handlowa w Warszawie, Warszawa.

Winiecki J., 2002. Transition economies and foreign trade. Routledge, London, New York.

World Bank 2010. Enhancing regional trade integration in Southeast Europe. IBRD, Washington, D.C.

World Bank 2014. World development indicators. [Online] Available at: http:// databank.worldbank.org/ data.

World Bank 2014. World integrated trade solution. [Online] Available at: http:// wits.worldbank.org/ Default.aspx [accessed 29 April 2014]. 